\title{
Diversity of the Rhopalodiaceae Diatoms (Bacillariophyta) on Macrophytes of Different Architecture in Small and Shallow Oxbow Lakes (SE Poland)
}

\author{
Mateusz Rybak ${ }^{1 *}$, Natalia Kochman-Kędziora², Wojciech Pęczuła ${ }^{3}$ \\ 1 University of Rzeszów, Faculty of Biology and Agriculture, Department of Agroecology, 35-601 Rzeszów, \\ Poland \\ 2 University of Rzeszow, Department ofEcology and Environmental Protection,Zelwerowicza 4,35-601 Rzeszów, \\ Poland \\ ${ }^{3}$ University of Life Sciences in Lublin, Department of Hydrobiology and Protection of Ecosystems, \\ Dobrzańskiego 37, 20-262 Lublin, Poland \\ * Corresponding author's e-mail: matrybak91@gmail.com
}

\begin{abstract}
The research was conducted in July 2018 on six oxbow lakes of the San River. A total of 21 samples from various macrophyte species were collected. Over 400 species of diatoms were identified in the analyzed materials, 9 of which belonged to the Rhopalodiaceae family. Most of these Epithemia and Rhopalodia species developed as dominants in most of the studied samples. One of reported species - Epithemia selengaensis Vishnyakov, Kulikovskiy \& Genkal was first time reported from Poland. The aim of the study was to present the taxonomic diversity of the representatives of the Rhopalodiaceae family growing different macrophyte species in oxbow lakes in the summer aspect.
\end{abstract}

Keywords: epiphytic algae, Epithemia, Rhopalodia, macrophytes, ecology, San River, taxonomy

\section{INTRODUCTION}

Communities of primary producers (macrophytes, phytoplankton and benthic algae) play a crucial role in supporting various food webs within the aquatic ecosystem (Špoljar et al. 2017). Nevertheless, the benthic algal communities (including epiphytic) represent an important component of food webs as primary producers, particularly in oligo-mesotrophic shallow lakes or littoral zones, where high water transparency results in higher light availability for microorganisms living below the water surface (Sierszen et al. 2006). Apart from its ecological role, algal epiphytic communities are also used in the assessment of the ecological status of aquatic ecosystems. It applies primarily to diatoms, which fulfill many the requirements of being useful indicator organisms in running waters, although several studies showed that the diatom analyses may also be applied to determine the ecological status of lentic ecosystems, especially shallow lakes (Kitner, Poulícková 2003, Cejudo-Figueiras et al. 2011, Blanco et al. 2014, MacDougall et al. 2017). It seems to be broadly accepted that the bioassessment methods based on epiphytic diatoms may be also effective for tracking the past changes under the environmental conditions of lakes or even small ponds (Wiklund et al. 2010, Emson et al. 2018).

The studies concerning epiphytic diatoms in small and shallow water bodies like ponds or oxbow lakes are relatively scarce, despite the fact that small waterbodies play an important role in the structure of biodiversity on both landscape and species level (Scheffer et al. 2006, Cereghino et al. 2008). The importance of oxbow lakes in Europe as biodiversity hot-spots was acknowledged by EC Habitats Directive 
92/43/EEC; thus, they became protected under the name "Habitat 3150" (Nowak et al. 2015). Their presence in the river valleys enriches biodiversity as habitats form protected, rare, valuable and disappearing species of vascular plants (Michalska-Hejduk et al. 2009) but also other organisms. In oxbow lakes, which usually are small and shallow water bodies, macrophytes play a crucial role in the ecosystem functioning; thus, the structure of aquatic plants is the main indicator which is used in the bioassessement of their conservation status (Wilk-Woźniak et al. 2019). As other shallow lake ecosystems with differentiated macrophyte architecture they offer an excellent habitat for epiphytic diatom assemblages (Letáková et al. 2018).

Rhopalodiaceae (Karsten) Topachevs'kyj and Oksiyuk (Round et al. 1990) are one of only two families within the Rhopalodiales order. Among several small genera only two: Rhopalodia and Epithemia contain several dozen of species. The most characteristic feature of species within this two genera is the presence of 2-5 cyanobacterial endosymbionths (Geitler 1977, Janson 2002). The cell walls of both genera are similar in symmetry, being strongly dorsiventral. The raphe of Rhopalodia species is positioned on the dorsal side, in a shallow keel, whereas the raphe of the species within the Epithemia genus is positioned along the ventral margin, with simple or slightly expanded raphe endings. In contrast to Epithemia, Rhopalodia cells have no girdle bands (Round et al. 1990, Taylor, Cocquyt 2016). Most of the Epithemia species are cosmopolitan and have worldwide distribution, although generally prefer temperate climates. They are widespread in almost all freshwaters, growing on submerged vegetation or more seldom in epilithic assemblages (Sims 1983, Krammer, Lange-Bertalot 1988). The Epithemia species reaches the maximum abundance especially in those microhabitats where phosphorus is relatively more available (DeYoe 1992, Kociolek et al. 2015).

The representatives of the Rhopalodiaceae family, due to the large cell size and wide geographical distribution, are well known species, often described more than 100 years ago. However, the taxa belonging to the two discussed genera, are usually identified only to the species level, based on a broad species concept. As a result the real diversity and within the family is often underestimated.
The paper discusses the variability and occurrence of the diatom taxa from the Rhopalodiaceae family from six oxbow lakes in the San river catchment area. All noted species developed on the submerged macrophytes. Additional information about morphology, ecology of Rhopalodia and Epithemia taxa based on observed populations was provided.

\section{STUDY AREA}

The San River, the largest of Carpathian rivers, is $458 \mathrm{~km}$ long. It is also one of the main tributaries of Vistula River. Oxbow lakes are very numerous in the San catchment area, especially along the middle and lower sections of the river.

The study was conducted in six oxbow lakes formed by the San River (south-eastern Poland) in its middle (sites P1, P2, M1, H1) and lower (Z1, Z2) course (Fig. 1). First two (P1 and P2) are located in the outskirts of the Przemyśl city $\left(49^{\circ} 47^{\prime} \mathrm{N}, 22^{\circ} 46^{\prime} \mathrm{E}\right)$. These water bodies with an area of 0.22 and 0.11 ha, are part of a larger group, located close to the San River, in the vicinity of allotment gardens. The area of both water bodies is overgrown with aquatic and waterside vegetation. Another two study sites (H1 and M1) are situated east of Przemyśl, close to the state border with Ukraine. The largest of studied oxbow lakes in the village Hurko (H1), with an area of ca. 10 ha, is used for fishery. The site M1 is a part of vast park surrounding the old historical palace in Medyka village, thus playing a role of a landscape pond. Both lakes (H1, M1), being under the influence of the human activity, have rather scarce aquatic vegetation, which was removed during its management. During the field studies in these lakes, a cyanobacterial bloom was observed. The sites Z1 and Z2, situated in the lower course of the San River have the most natural character. They are located within the NATURA 2000 Special Area of Conservation "Dolina Dolnego Sanu" (PLH180020), situated between Stalowa Wola $\left(50^{\circ} 34^{\prime} \mathrm{N}, 22^{\circ} 03^{\prime} \mathrm{E}\right)$ and Sandomierz $\left(50^{\circ} 40^{\prime} \mathrm{N}, 21^{\circ} 44^{\prime} \mathrm{E}\right)$, close to the village Zaleszany. Both sites are part of socalled "Old San", the largest of the river-beds in the lower course of the San River, with several arms stretched between two present river beds (San and Łęg rivers) (Prarat 2009, MichalskaHejduk et al. 2009). 


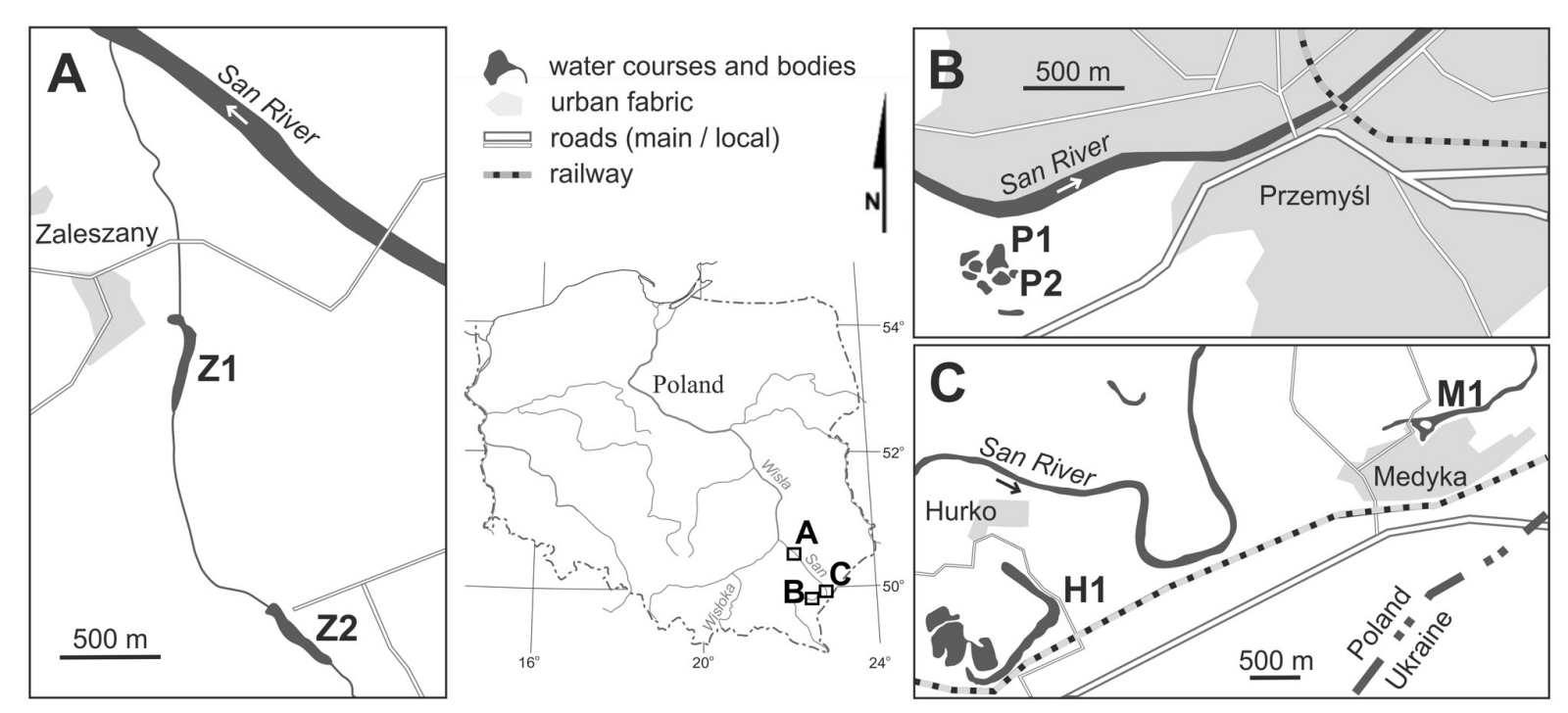

Figure 1. Situation map of six studied oxbow lakes

\section{METHODS}

The diatom material was collected in July 2018 from six different oxbow lakes in four localities. The samples were taken from dominant macrophytes (floating leaves (FLM), emergent (EM) and submerged plants (SM). A total of 21 samples were collected, separately for each of the macrophyte species (Table 1). The plant species identification was based on Kłosowski, Kłosowski (2010).

Water temperature, oxygen concentration, $\mathrm{pH}$ and conductivity were measured in situ during sampling, with the use of a MARTINI PH65 meter, a MARTINI EC59 meter and a HANNA HI 9146 oxygen meter, respectively. An additional water sample for the chemical analyses (listed in Table 2) was taken from the central part of each oxbow lake. Those analyses were performed using a DIONEX ICS-5000 + DC Thermo scientific ion chromatograph in a laboratory.

The diatom samples were cleaned by adding $30 \% \mathrm{H}_{2} \mathrm{O}_{2}$ and heating until the organic matter is digested $(1-2 \mathrm{~h})$. The reaction was completed by the addition of $\mathrm{HCl}$. Following digestion and centrifugation (5 times, 5 minutes at $2500 \mathrm{rpm}$ ) with distilled water, the resulting cleaned material was mounted in Pleurax (refractive index 1.75). The diatoms were identified and counted under a Carl Zeiss Axio Imager A2 light microscope (LM) equipped with Differential Interference Contrast (Nomarski) optics, under 1000× magnification. The diatom images were captured using a Zeiss ICC 5 camera. The diatom identification was based on: Hofmann et al. (2011), Lange-Bertalot et al. (2017), Kulikovskiy et al. (2016) and Qingmin et al. (2009). The species composition was determined by counting 300 valves on randomly selected transects under LM.

Recently, Cocquyt et al. (2018) degraded the Rhopalodia genus to the rank of subgenus in the Epithemia genus, but for the purposes of this study, the authors used the classification of genera provided by Round et al. (1990).

\section{RESULTS}

The values of physical and chemical parameters measured in the study are shown in Table 2. Temperature $\left(23.8-26.3^{\circ} \mathrm{C}\right)$ and $\mathrm{pH}$ values (7.4-8.5) fell within the ranges expected for the oxbow lakes in Central Europe in summer. Some differentiation among the studied lakes were observed in electrolytic conductivity. The lowest values of conductivity were measured at sites $\mathrm{Z} 1$ and $\mathrm{Z} 2$ in Zaleszany (347-367 $\left.\mu \mathrm{S} \mathrm{cm}^{-1}\right)$. The rest of lakes had conductivity in the range 500-565 $\mu \mathrm{S} \mathrm{cm}^{-1}$ except P2 site in Przemyśl, where twice as high values of this parameter were found, as compared to Z1 and Z2 sites (Table 2). The water in all studied lakes was rich in chlorides (17.72-67.54 $\left.\mathrm{mg} \mathrm{l}^{-1}\right)$ and calcium (26.5-83.3 $\mathrm{mg} \mathrm{l}^{-1}$ ) but had very low values (below the limit of determination) of nitrates and phosphates (with the exception of site M1).

More than 400 diatom taxa were identified in 21 samples. The number of taxa noted in each sample ranged from 40 (sample 2018/152 collected from Potamogeton lucens at site P1) to 137 
Table 1. List of samples used in this study with detailed information about sites, geographic coordinates and the macrophytes samples were taken from.

\begin{tabular}{|c|c|c|c|c|}
\hline Site & Samples & GPS data & Vegetation & \\
\hline \multirow{3}{*}{ Medyka (M1) } & 2018/144 & \multirow{3}{*}{$\begin{array}{l}49^{\circ} 48^{\prime} 31.9^{\prime \prime} \mathrm{N} \\
22^{\circ} 55^{\prime} 58.66^{\prime \prime} \mathrm{E}\end{array}$} & Ceratophyllum demersum L. & SM \\
\hline & $2018 / 146$ & & Phragmites australis (Cav.) Trin. ex Steud. & EM \\
\hline & $2018 / 147$ & & Lemno-Spirodeletum (Koch, 1954) & FLM \\
\hline Hurko $(\mathrm{H} 1)$ & $2018 / 142$ & $\begin{array}{l}50^{\circ} 39^{\prime} 24.6 " \mathrm{~N} \\
21^{\circ} 55^{\prime} 21.77^{\prime \prime}\end{array}$ & Phragmites australis (Cav.) Trin. ex Steud. & EM \\
\hline \multirow{3}{*}{ Przemyśl (P1) } & $2018 / 150$ & \multirow{3}{*}{$\begin{array}{l}49^{\circ} 46^{\prime} 39.8^{\prime \prime} \mathrm{N} \\
22^{\circ} 44^{\prime} 41.0^{\prime \prime} \mathrm{E}\end{array}$} & Hydrocharis morsus-ranae L. & FLM \\
\hline & $2018 / 151$ & & Typha sp. & EM \\
\hline & $2018 / 152$ & & Potamogeton lucens L. & SM \\
\hline \multirow{5}{*}{ Przemyśl (P2) } & $2018 / 154$ & \multirow{5}{*}{$\begin{array}{l}49^{\circ} 46^{\prime} 38.0^{\prime \prime} \mathrm{N} \\
22^{\circ} 44^{\prime} 44.6^{\prime \prime} \mathrm{E}\end{array}$} & Hydrocharis morsus-ranae L. & FLM \\
\hline & $2018 / 155$ & & Potamogeton lucens L. & SM \\
\hline & $2018 / 156$ & & Myriophyllum spicatum L. & SM \\
\hline & $2018 / 157$ & & Typha sp. & EM \\
\hline & 2018/158 & & Utricularia australis $\mathrm{R} . \mathrm{Br}$. & SM \\
\hline \multirow{5}{*}{$\begin{array}{l}\text { Zaleszany } \\
\text { (Z1) }\end{array}$} & $2018 / 131$ & \multirow{5}{*}{$\begin{array}{l}50^{\circ} 40^{\prime} 07.1^{\prime \prime} \mathrm{N} \\
21^{\circ} 54^{\prime} 54.9^{\prime \prime} \mathrm{E}\end{array}$} & Hydrocharis morsus-ranae L. & FLM \\
\hline & $2018 / 133$ & & Salvinia natans (L.) All. & FLM \\
\hline & $2018 / 134$ & & Nuphar lutea (L.) Sibth. \& Sm. & FLM \\
\hline & $2018 / 135$ & & Myriophyllum spicatum L. & SM \\
\hline & $2018 / 136$ & & Ceratophyllum demersum L. & SM \\
\hline \multirow{4}{*}{$\begin{array}{l}\text { Zaleszany } \\
\text { (Z2) }\end{array}$} & $2018 / 137$ & \multirow{4}{*}{$\begin{array}{l}50^{\circ} 39^{\prime} 24.66^{\prime \prime} \mathrm{N} \\
21^{\circ} 55^{\prime} 21.77^{\prime \prime} \mathrm{C}\end{array}$} & Hydrocharis morsus-ranae L. & FLM \\
\hline & $2018 / 139$ & & Salvinia natans (L.) All. & FLM \\
\hline & $2018 / 140$ & & Nuphar lutea (L.) Sibth. \& Sm. & FLM \\
\hline & $2018 / 141$ & & Phragmites australis (Cav.) Trin. ex Steud. & EM \\
\hline
\end{tabular}

(sample 2018/146) on Phragmites australis in Medyka (site M1) (Table 3). Among all recorded taxa, nine belong to the Rhopalodiaceae family, from which seven Epithemia and two Rhopalodia taxa were noted in all studied samples, but in variable abundance (Table 3 ). At the sites devoid of their ,semi-natural" character (H1, M1), the Rhopalodiaceae taxa were noted only occasionally, whereas in macrophyte dominated oxbow lakes of more "natural" character (P1, P2, Z1, Z2), they developed more numerously. The diatoms from that family dominated the assemblages in some cases: in six from twenty one studied samples, Rhopalodiaceae reached together more than $50 \%$ off all counted valves. Among them, in the sample collected from Myriophyllum spicatum (2018/135), the diatom community was entirely dominated by Epithemia and Rhopalodia taxa. However, no preferences of individual taxa in relation to macrophytes were observed.

Below, the population characteristics of Rhopalodiaceae taxa found in the study are presented.

Epithemia adnata var. adnata (Kützing) Rabenhorst (Fig. 2: 7-10)

Population characteristic: length 23.2-87.4 $\mu \mathrm{m}$, width $7.4-10.3 \mu \mathrm{m}$, striae $14-16$ in $10 \mu \mathrm{m}$, costae

Table 2. Physico-chemical parameters of water in the six studied oxbow lakes.

\begin{tabular}{|l|c|c|c|c|c|c|}
\hline \multicolumn{1}{|c|}{ Sites } & $\mathrm{M} 1$ & $\mathrm{H} 1$ & $\mathrm{P} 1$ & $\mathrm{P} 2$ & $\mathrm{Z} 1$ & $\mathrm{Z} 2$ \\
\hline Temperature $\left[{ }^{\circ} \mathrm{C}\right]$ & 25.3 & 26.3 & 23.8 & 25.4 & 26.1 & 24.5 \\
\hline $\mathrm{pH}$ & 8.5 & 7.9 & 7.7 & 7.4 & 7.7 & 7.4 \\
\hline Conductivity $\left[\mu \mathrm{S} \mathrm{cm}^{-1}\right]$ & 523 & 500 & 565 & 728 & 347 & 367 \\
\hline $\mathrm{O}_{2}\left[\mathrm{mg} \mathrm{l}^{-1}\right]$ & 5.68 & 4.86 & 6.10 & 2.15 & 1.54 & 1.87 \\
\hline $\mathrm{Cl}^{-}\left[\mathrm{mg} \mathrm{l}^{-1}\right]$ & 67.54 & 25.11 & 28.40 & 25.58 & 20.38 & 17.72 \\
\hline $\mathrm{SO}_{4}^{2-}\left[\mathrm{mg} \mathrm{l}^{-1}\right]$ & 15.94 & 26.25 & 19.19 & 13.44 & 3.07 & 14.22 \\
\hline $\mathrm{PO}_{4}{ }^{3-}\left[\mathrm{mg} \mathrm{l}^{-1}\right]$ & 0.47 & $<0.001$ & $<0.001$ & $<0.001$ & $<0.001$ & $<0.001$ \\
\hline $\mathrm{NO}_{3}^{-}\left[\mathrm{mg} \mathrm{l}^{-1}\right]$ & $<0.001$ & $<0.001$ & $<0.001$ & $<0.001$ & $<0.001$ & $<0.001$ \\
\hline $\mathrm{NH}_{4}^{+}\left[\mathrm{mg} \mathrm{l}^{-1}\right]$ & 0.46 & 0.21 & 0.18 & 0.15 & 0.24 & 0.45 \\
\hline $\mathrm{Mg}^{2+}\left[\mathrm{mg} \mathrm{l}^{-1}\right]$ & 8.03 & 15.05 & 12.26 & 12.48 & 7.47 & 6.63 \\
\hline $\mathrm{Ca}^{2+}\left[\mathrm{mg} \mathrm{l}^{-1}\right]$ & 26.52 & 44.52 & 56.22 & 83.26 & 30.49 & 28.61 \\
\hline
\end{tabular}


Table 3. The presence and percentage of counted valves in diatom assemblages of studied taxa. The highest values are in bold, + taxon observed occasionally, reaching up to $1 \%, \mathbf{T}$ - total number of identified taxa, EAVA - Epithemia adnata var. adnata, EAVP - Epithemia adnata var. probiscidea, EAVS - Epithemia adnata var. saxonica, EFRI - Epithemia frickei, ESEL - Epithemia selengaensis, ESOR - Epithemia sorex, ETUR - Epithemia turgida, RGVG - Rhopalodia gibba var. gibba, RGVM - Rhopalodia gibba var. minuta.

\begin{tabular}{|c|c|c|c|c|c|c|c|c|c|c|c|}
\hline \multicolumn{2}{|r|}{ Samples } & $\mathrm{T}$ & EAVA & EAVP & EAVS & EFRI & ESEL & ESOR & ETUR & RGVG & RGVM \\
\hline \multirow{3}{*}{ M1 } & Ceratophyllum demersum & 108 & + & & & & & & + & & \\
\hline & Phragmites australis & 137 & + & + & & & & + & + & + & \\
\hline & Lemno-Spirodeletum & 75 & + & + & & & + & & + & + & \\
\hline $\mathrm{H} 1$ & Phragmites australis & 73 & + & + & & + & + & + & + & + & \\
\hline \multirow{3}{*}{$\mathrm{P} 1$} & Hydrocharis morsus-ranae & 88 & 33.6 & 8.9 & & & & + & 2.5 & 9.5 & \\
\hline & Typha sp. & 123 & 2.2 & 28.4 & + & & & 2.2 & 1.5 & 12.7 & \\
\hline & Potamogeton lucens & 40 & 36.6 & 13.4 & & & & 12.5 & 3.5 & 22.3 & \\
\hline \multirow{5}{*}{ P2 } & Hydrocharis morsus-ranae & 72 & 14.1 & 10.9 & & & & & + & 1.6 & \\
\hline & Potamogeton lucens & 42 & 13.2 & 28.5 & & & & + & 4.9 & 31.9 & + \\
\hline & Myriophyllum spicatum & 81 & 15 & 12.9 & & & & & + & 4.1 & \\
\hline & Typha sp. & 84 & 8 & 4.5 & + & & + & & + & 2.3 & \\
\hline & Utricularia australis & 69 & + & 16.8 & & & & & + & 17.5 & \\
\hline \multirow{5}{*}{$\mathrm{Z1}$} & Hydrocharis morsus-ranae & 65 & 11.7 & + & & + & & + & 5.6 & + & \\
\hline & Salvinia natans & 76 & 8.4 & + & & + & & + & 3.8 & 8.4 & \\
\hline & Nuphar lutea & 68 & 31.3 & + & + & & & + & + & 20.9 & \\
\hline & Myriophyllum spicatum & 50 & 21.9 & + & & + & & + & 10.5 & 66.6 & + \\
\hline & Ceratophyllum demersum & 62 & 28.8 & + & & + & & & 5.1 & 5.1 & \\
\hline \multirow{4}{*}{$\mathrm{Z2}$} & Hydrocharis morsus-ranae & 89 & 10.3 & 4.2 & & & & + & + & 4.1 & \\
\hline & Salvinia natans & 93 & + & + & + & & & + & + & + & \\
\hline & Nuphar lutea & 56 & 23.8 & 23.8 & & & & + & 24.6 & 6.9 & \\
\hline & Phragmites australis & 50 & 13.4 & 20.3 & + & + & & + & 5.9 & 2.7 & + \\
\hline
\end{tabular}

3-8 in $10 \mu \mathrm{m}$. The taxon was observed in all studied samples, often formed numerous population. In the reservoirs that keep their natural character $(\mathrm{P} 1, \mathrm{P} 2$, $\mathrm{Z1}, \mathrm{Z2}$ ) it dominates the diatom flora, and reached up to $36.6 \%$ of total diatom abundance in the sample 2018/152. On the contrary, at sites M1 and H1, this variety was observed only occasionally.

Epithemia adnata var. proboscidea (Kützing) Hendey (Fig. 2: 1-5)

Population characteristic: length $26.7-100 \mu \mathrm{m}$, width 7.4-10.2 $\mu \mathrm{m}$, striae $14-16$ in $10 \mu \mathrm{m}$, costae $3-8$ in $10 \mu \mathrm{m}$. The taxon co-occurs with nominal form in all studied samples, often formed numerous populations (up to $28.5 \%$ of total diatom abundance in sample 2018/155). Only at sites M1, H1, Z1 in Zaleszany, it was less frequent.

Epithemia adnata var. saxonica (Kützing) R.M.Patrick (Fig. 3: 13-16)

Population characteristic: length $25.5-90.2 \mu \mathrm{m}$, width $8-9.4 \mu \mathrm{m}$, striae $12-15$ in $10 \mu \mathrm{m}$, costae $3-6$ in $10 \mu \mathrm{m}$. This variety was observed only in form of individual specimens together with other varieties of E. adnata.

Epithemia frickei Krammer in Lange-Bertalot \& Krammer (Fig. 2: 6)
Population characteristic: length $27-85 \mu \mathrm{m}$, width $10.4-12.4 \mu \mathrm{m}$, striae $12-13$ in $10 \mu \mathrm{m}$, costae 2-4 in $10 \mu \mathrm{m}$. Only few specimens were observed in the samples from Zaleszany (both sites) and Hurko. Observed valves were large, reached the upper range of dimensions for this taxa.

Epithemia selengaensis Vishnyakov, Kulikovskiy \& Genkal (Fig. 2: 11-12)

Population characteristic: length $30-58 \mu \mathrm{m}$, width $8-12 \mu \mathrm{m}$, striae $10-12$ in $10 \mu \mathrm{m}$, costae $2-3$ in $10 \mu \mathrm{m}$. Single specimens of these species were observed in only three samples from upper part of San river, both in lakes subjected to the anthropogenic pressure (H1, M1) and the natural one (P2).

Epithemia sorex Kützing (Fig. 3: 8-12)

Population characteristic: length $10-45 \mu \mathrm{m}$, width $7-8.2 \mu \mathrm{m}$, striae $13-16$ in $10 \mu \mathrm{m}$, costae 5-7 in $10 \mu \mathrm{m}$. The species was found in each of studied oxbow lakes, but mainly occasionally. Only at site P1 it formed larger population on Potamogeton lucens $(12.5 \%$ of all counted valves).

Epithemia turgida (Ehrenberg) Kützing (Fig. 3: 1-3) 


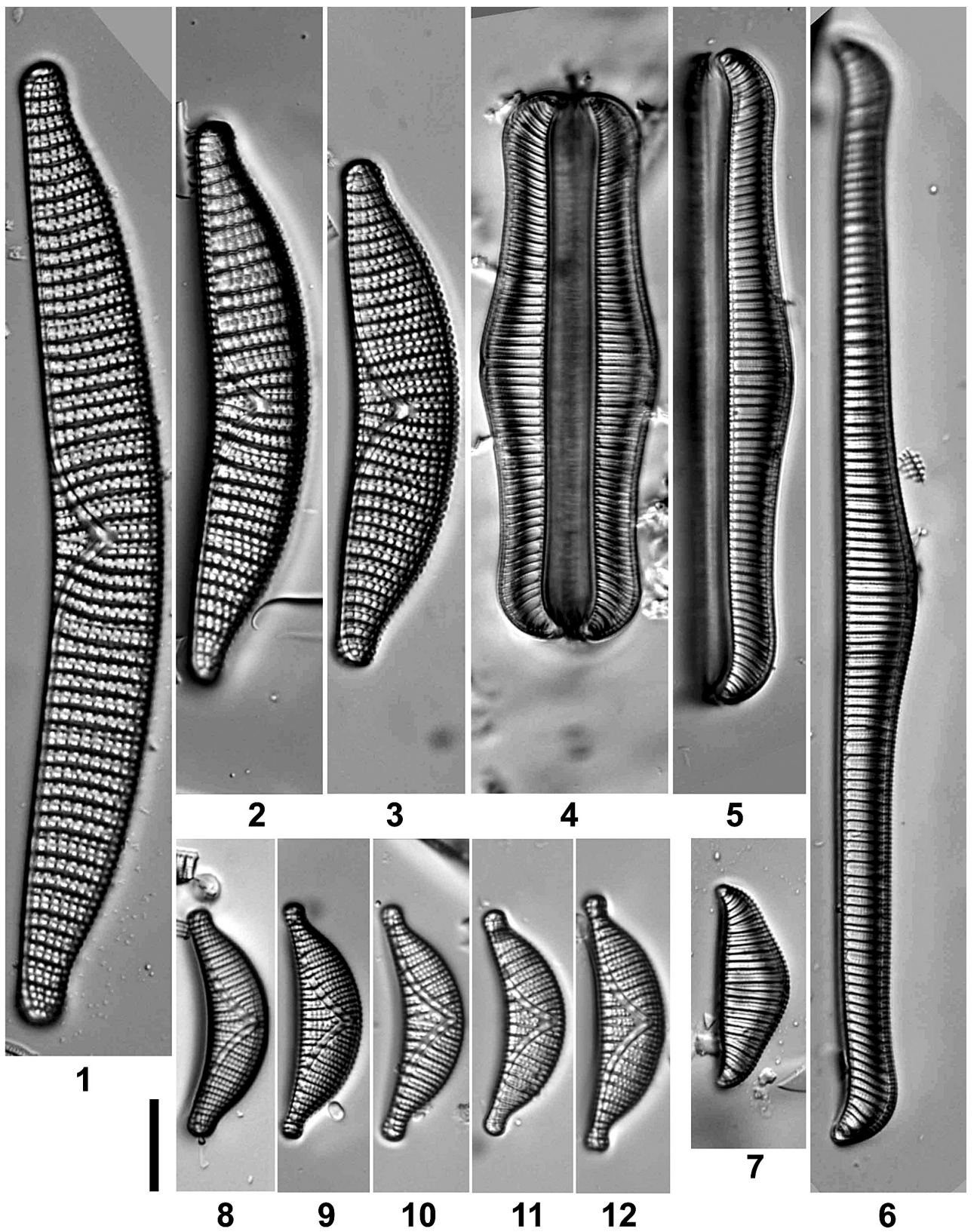

Figure 2. LM pictures of Epithemia and Rhopalodia taxa recorded in samples collected from different macrophytes. 1-3 - Epithemia turgida, 4-6-Rhopalodia gibba, 7 - Rhopalodia gibba var. minuta, 8 - Epithemia sorex.

Population characteristic: length $44-140.4 \mu \mathrm{m}$, width $14-17.8 \mu \mathrm{m}$, striae $7-8$ in $10 \mu \mathrm{m}$, costae $3-5$ in $10 \mu \mathrm{m}$. The species was observed in all studied samples, usually reached few percent of all valves counted in each sample. Only in sample 2018/140, the species was more numerous $(24.6 \%$ of all counted valves). This sample was collected from Nuphar lutea.

Rhopalodia gibba (Ehrenberg) O.Müller (Fig. 3: 4-6)

Population characteristic: lenght $10-210 \mu \mathrm{m}$, width $8.7-11 \mu \mathrm{m}$, striae $14-16$ in $10 \mu \mathrm{m}$, costae
6-8 in $10 \mu \mathrm{m}$. The species was observed in almost all studied samples (with exception of sample 2018/144), where often formed numerous populations (exceeding 5\% share in an assemblage). The most frequent population was noted in the sample collected from Myriophyllum spicatum.

Rhopalodia gibba var. minuta Krammer (Fig. 3: 7)

Population characteristic: length $25-29 \mu \mathrm{m}$, width $8.4-8.9 \mu \mathrm{m}$, striae $14-16$ in $10 \mu \mathrm{m}$, costae $7-8$ in $10 \mu \mathrm{m}$. Only few specimens were observed together with nominal variety. 

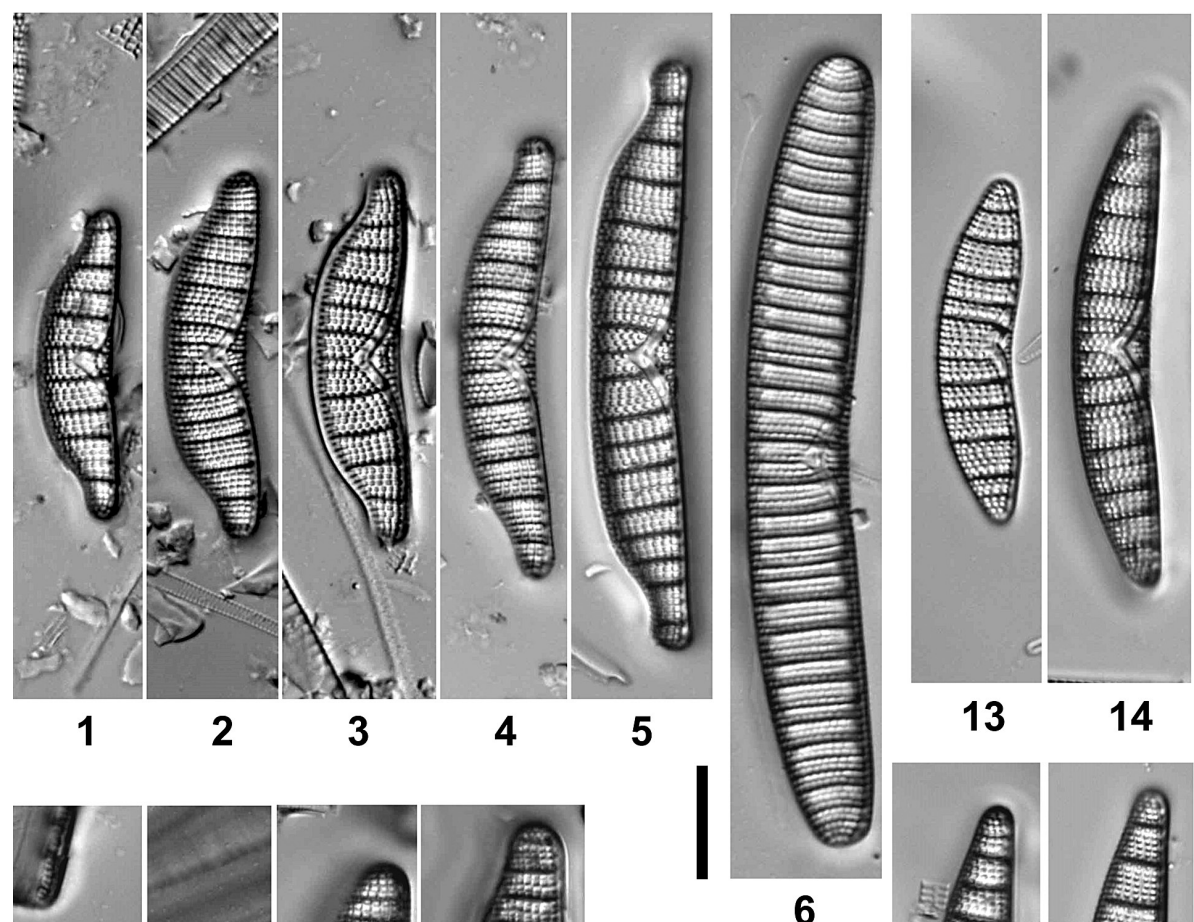

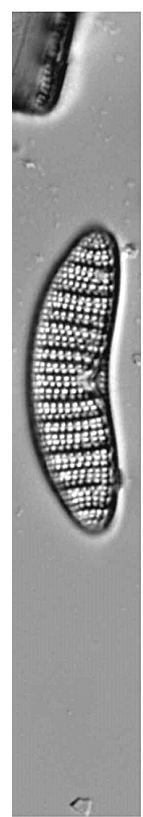

7

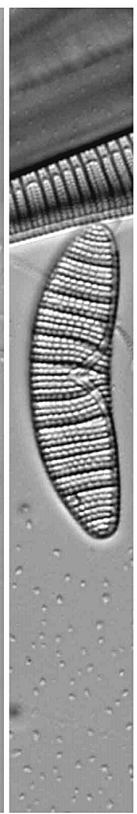

8

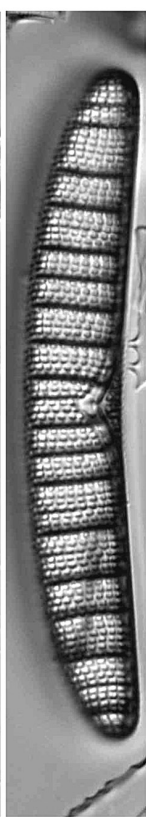

9

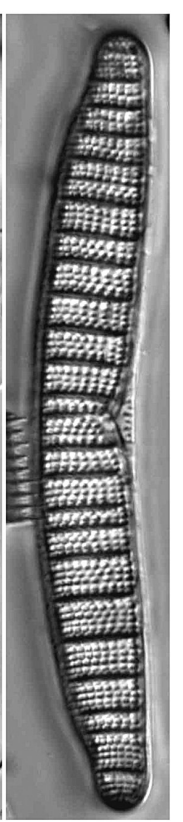

10

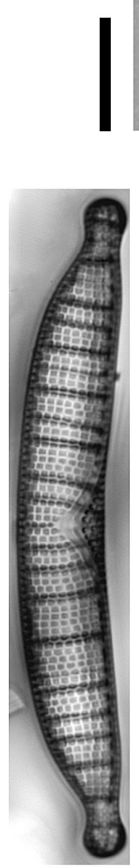

11

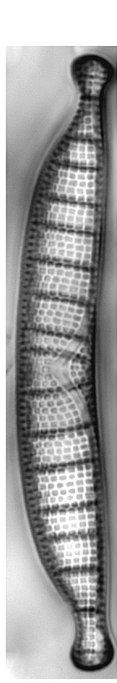

12

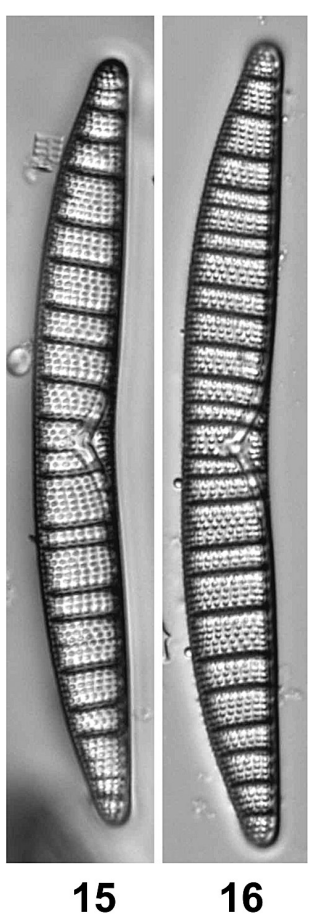

Figure 3. LM pictures of Epithemia taxa recorded in samples collected from different macrophytes.

1-5 - Epithemia adnata var. proboscidea, 6-Epithemia frickei, 7-10 - Epithemia adnata var. adnata, 11-12 - Epithemia selengaensis, 13-16 - Epithemia adnata var. saxonica

\section{DISCUSSION}

The oxbow lakes can develop as a result of isolation/disconnection from meander necks or separation from rivers by riverside embankments during freshets (Żmudziński et al. 2002, Dembowska, Napiórkowski 2012, Dembowska et al. 2012). The oxbow lake has many important functions in river valley ecosystems, where together with rivers and their catchments it contributes to the natural diversity of those areas. Apart their hydrological and microclimatic role of retention reservoirs, oxbow lakes form a suitable and supportive environment for the growth of water and hygrophilous flora, as well as valuable habitat for wildlife (Glińska-Lewczuk 2009, Koc et al. 2009).

In general, in all studied oxbow lakes more or less similar values of water temperature, $\mathrm{pH}$ and conductivity were noted, which is in accordance with the results presented by Michalska-Hejduk et al. (2009) in the same locality. Only the oxygen content was higher $(2.52-4.21 \mathrm{mg} / \mathrm{l})$ than in our samples, which is probably connected with differences in the weather conditions and water temperature. 
Oxbow lakes are considered as natural eutrophic water bodies. However, as a result of macrophyte and phytoplankton activities, the levels of soluble mineral forms of nutrients in such lakes can be very low, as it was noted in the studied lakes (Reddy et al. 1989, 1990, Olguín et al. 2007, Ozimek et al. 1990, Upadhyaya et al. 2007). The low values of the analyzed ions might also be a result of the oxbow separation from the river, as it was revealed by Glińska-Lewczuk (2009). In her study, in the comparison of two types of oxbow lakes: lentic and lotic, it was demonstrated that various ions are withdrawn from the system. The oxbow lakes separated from the river showed significantly lower values of nitrates and nitrites. In lentic oxbow lakes, isolated from the river, the matter cycling (mainly organic) influences the change and development of the specific macrophytes species composition. The plant species in this type of habitat are well adapted to the anoxic conditions and decreased productivity (Glińska-Lewczuk 2009).

From seven identified in this study Epithemia species, E. selengaensis was reported for the first time from Poland. The species was described in 2014 from Selenga River delta in Russia, but was also observed in the samples from lakes in Mongolia and Eastern Baikal Region (Vishnyakov et al. 2014). The species was also recorded on macrophytes in various types of water in Turkey (C. Solak - pers. comm.). E. selengaensis belongs to E. adnata group but can be easily distinguished on the basis of roundly capitate apices. Other Rhopalodiaceae noted during our study belong to commonly reported taxa. Unfortunately, all of them are identified in wide species concept, very often only to the species level. They are widespread in fresh and brackish waters and prefer waters rich in calcium, meso- to eutrophic. They occur mainly in epiphytic, more seldom in epilithic assemblages in stagnant and slowly floating waters (Hofmann et al. 2011, Lange-Bertalot et al. 2017, Pliński, Witkowski 2013).

The studied taxa were found on each of the analyzed macrophytes. The most numerous population was formed by Epithemia adnata s.l., following by E. turgida and Rhopalodia gibba s.l. The semi-natural oxbow lakes (i.e. in Przemyśl city) overgrown by various macrophytes favor the development of epiphytic diatom species. The stagnant, freshwater ecosystems is Europe are very often overgrown by macrophytes. Among the epiphytic diatom assemblages growing on various macrophytic plants, many authors report the dominance of species from the Rhopalodiaceae, especially E.adnata s.1., E. sorex, R.gibba (Kuczyńska-Kippen et al. 2005, Laugaste, Reunanen 2005, Toporowska et al. 2008). In the samples taken from the lakes where the cyanobacterial bloom persisted (site H1, M1), the discussed species developed rarely and assemblages were manly dominated by typically epiphytic taxa. On stems of Phragmites australis and on Ceratophylum demersum the most common taxa were: Cocconeis placentula Ehrenberg, C. lineata Ehrenberg and Cymbella subleptoceros Krammer. In plant community "Lemno-Spirodeletum" diatom assemblages was dominated by $C$. lineata Ehrenberg, Halamphora veneta (Kützing) Levkov and Lemnicola hungarica (Grunow) Round \& Basson. Moreover, Lemnicola hungarica is reported as a species associated with various Lemnaceae species (Buczkó 2007, Emson et al. 2018).

In addition to the dominance of macrophytes, also the nitrogen limitation tends to give preferential conditions for the Rhopalodiaceae diatoms (Fairchild et al. 1985, Hill, Knight 1988, Peterson, Grim 1992). This species have endosymbionts capable of fixing the atmospheric nitrogen. Marks, Lowe (1993) reported that E. adnata is a nitrogen specialist, often dominates epiphytic microhabitats where the ratio of available nitrogen to phosphorous might be relatively low.

The Epithemia and Rhopalodia genera contain mainly the species considered as polytypic, containing many varieties. However, in most commonly used keys (Hofmann et al. 2011, Lange-Bertalot et al. 2017), only the broad species concept is given for most of them, resulting in poor understanding of ecological preferences and the distribution of individual taxa of the Epithemia and Rhopalodia genera. Therefore, the actual diversity of the Rhopalodiaceae family is also overlooked.

\section{Acknowledgments}

The authors thank Marcin Pieniążek, MSc (Department of Soil Studies, Environmental Chemistry and Hydrology, Faculty of Biology and Agriculture, University of Rzeszów) for the chemical analyses of water samples.

The project, funded under the Polish Ministry of Science and Higher Education under the name of "Regional Excellence Initiative" in the years 2019-2022 Project No. 026/RID/2018/19. 


\section{REFERENCES}

1. Blanco S., Cejudo-Figueiras C., Álvarez-Blanco I., van Donk E., Gross E. M., Hansson L. A., Irvine K., Jeppesen E., Kairesalo T., Moss B., Nõges T., Bécares E. 2014. Epiphyticdiatoms along environmental gradients in Western European shallow lakes. CLEAN-Soil, Air, Water, 42(3), 229-235.

2. Buczkó K. 2007. The occurrence of the epiphytic diatom Lemnicola hungarica on different European Lemnaceae species. Fottea, Olomouc, 7(1), 77-84

3. Cejudo-Figueiras C., Álvarez-Blanco I., Bécares E., Blanco S. 2011. Epiphytic diatoms and water quality in shallow lakes: the neutral substrate hypothesis revisited. Marine and freshwater research, 61(12), 1457-1467.

4. Céréghino R., Biggs J., Oertli B., Declerck S. 2008. The ecology of European ponds: defining the characteristics of a neglected freshwater habitat. Hydrobiologia, 597, 1-6.

5. Cocquyt C., Kusber W.H., Jahn R. 2018. Epithemia hirudiniformis and related taxa within the subgenus Rhopalodiella subg. nov in comparision to Epithemia subgen Rhopalodia stat nov. (Bacillariophyceae) from East Africa. Cryptogamie, Algologie, 39(1), 35-62.

6. Dembowska E., Głogowska B., Dąbrowski K. 2012. Dynamics of algae communities in an oxbow lake (Vistula River, Poland). Archives of Polish Fisheries, 20, 27-37.

7. Dembowska E., Napiórkowski P. 2012. Dlaczego warto chronić starorzecza? Kosmos, 61(2), 341-349.

8. DeYoe H.R., Lowe R.L., Marks J.C. 1992. Effects of nitrogen and phosphorus on the endosymbiont load of Rhopalodia gibba and Epithemia turgida (Bacillariophyceae). Journal of Phycology, 28,773-777.

9. Emson, D., Sayer, C.D., Bennion, H. Patmor I.R., Rioual P. 2018. Mission possible: diatoms can be used to infer past duckweed (lemnoid Araceae) dominance in ponds. J Paleolimnol 60, 209-221

10. Fairchild G.W., Sherman J.W., Acker F.W. 1985. Algal periphyton growth on nutrient-diffusing substrates: An in situ bioassay. Ecology, 66, 465-472.

11. Geitler L. 1977. Zur Entwicklungsgeschichte der Epithemiaceen Epithemia, Rhopalodia und Denticula (Diatomophyceae) und ihre vermutlich symbiontischen Sphäroidkörper. Plant Systematics and Evolution, 128, 259-275.

12. Glińska-Lewczuk K. 2009. Water quality dynamics of oxbow lakes in young glacial landscape of NE Poland in relation to their hydrological connectivity, Ecological Engineering, 35, 25-37.

13. Gottschalk S., Kahlert M. 2012. Shifts in taxonomical andguild composition of littoral diatom assemblages along envi-ronmental gradients. Hydrobiologia, 694, 41-56.
14. Hill W.R., Knight A.W. 1988. Nutrient and light limitation of algae in two northern California streams. Journal of Phycology, 24, 125-132.

15. Hofmann G., Werum M., Lange-Bertalot H. 2011. Diatomeen im Süßwasser - Benthos von Mitteleuropa. Bestimmungsflora Kieselalgen für die ökologische Praxis. Über 700 der häugfisten Arten und ihre Ökologie. [In:] H. Lange-Bertalot, (Ed.). A.R.G. Gantner Verlag K.G., Ruggell, 908 pp.

16. Janson S. 2002. Cyanobacteria in symbiosis with diatoms. [In:] A.N. Rai, B. Bergman,U. Rasmussen (Eds) Cyanobacteria in Symbiosis. Cluwer Academic Publishers, 1-10.

17. Kitner M., Poulícková A. 2003. Littoral Diatoms as Indicators for the Eutrophication of Shallow Lakes, Hydrobiologia, 506/509, 519-524.

18. Kłosowski S., Kłosowski G. 2010. Flora Polski. Rośliny wodne i bagienne. Multico. Oficyna Wydawnicza, 333 pp.

19. Koc J., Kobus S., Glińska-Lewczuk K. 2009. The significance of oxbow lakes for the ecosystem of afforested river valleys. J. Water Land Dev. 13a, 115-131.

20. Kociolek J.P., Spaulding S.A., Lowe R.L. 2015a. Bacillariophyceae: the raphid diatoms. Chapter 16. [In:] J. Wehr, R. Sheath, J.P. Kociolek (Eds): Freshwater algae of North America, ed. 2., Academic Press, New York, 707-770.

21. Krammer K., Lange-Bertalot H. 1988. Bacillariophyceae 2. Bacillariaceae, Epithemiaceae, Surirellaceae . [In:] H. Ettl, J. Gerloff, H. Heyning, D. Mollenhauer (Eds): Süsswasserflora von Mitteleuropa 2(1), G. Fischer Verlag,. Jena, 600 pp.

22. Kuczyńska-Kippen N., Messyasz B., Nagengast B., Celewicz S., Klimko M. 2005. A Comparative study of periphyton communities on reed complex and Chara tomentosa in three shallow lakes of Wielkopolska area, Poland. Biologia, 60(4), 349-355

23. Kulikovskiy M., Glushchenko A.M., Genkal S.I., Kuznetsova I.V. 2016. Identyfication book of diatoms from Russia. Filigran. 803 pp.

24. Lange-Bertalot H., Hofmann G., Werum M., Cantonati M. 2017. Freshwater benthic diatoms of Central Europe: over 800 common species used in ecological assessments. English edition with updated taxonomy and added species. [In:] M. Cantonati et al. (Eds): Koeltz Botanical Books, Schmitten-Oberreifenberg, 942 pp.

25. Laugaste R., Reunanen M. 2005. The composition and density of epiphyton on some macrophyte species in the partly meromictic Lake Verevi. Hydrobiologia, 547, 137-150.

26. Letáková M., Fránková M.,Poulíčková A. 2018. Ecology and applications of freshwater epiphytic diatoms. Cryptogamie, Algologie, 39(1), 3-22. 
27. MacDougall M.J., Paterson A.M., Winter J.G., Jones F.C., Knopf L.A., Hall R.I. 2017. Response of periphytic diatom communities to multiple stressors influencing lakes in the Muskoka River watershed, Ontario, Canada. Freshwater Science, 36(1), 77-89.

28. Marks J.C., Lowe R.L. 1993. Interactive effects of nutrient availability and light levels on periphyton composition of large oligotrophic lake. Canadian Journal of Fisheries and Aquatic Sciences, 50(6), 1270-1278.

29. Michalska-Hejduk D., Kopeć D., Drobniewska A., Sumorok B. 2009. Comparison of physical and chemical properities of water and floristic diversity of oxbow lakes under different levels of human pressure: A case study of the lower San River (Poland). Ecohydrology and Hydrobiology, 9(2-4), 183-191.

30. Nowak, A., Maślak, M., Nobis, M., Nowak, S., Kojs, P., Śmieja, A., 2015. Is the riparian habitat creation an effective measure of plant conservation within the urbanized area? Ecol. Eng. 83, 125-134. https://doi.org/10.1016/j.ecoleng.2015.06.009.

31. Olguín E.J., Sánchez-Galván G., Pérez-Pérez T. 2007. Assessment of the phytoremediation potential of Salvinia minima Baker compared to Spirodela polyrrhiza in high-strenght organic wastewater. Water Air Soil Pollution, 181, 135-147.

32. Ozimek T., Gulati R.D., Donk E. 1990. Can macrophytes be useful in biomanipulation of lakes? The Lake Zwemlust example. Hydrobiologia, 200: 399-407.

33. Petersen C.G., Grimm N.B. 1992. Temporal variation in enrichment effects during periphyton succession in nitrogen-limited desert stream ecosystem. Journal of the North American Benthological Society 11(1): 20-36.

34. Pliński M., Witkowski A. 2013. Flora Zatoki Gdańskiej i wód przyległych cz. 4/4 (Bałtyk Południowy, okrzemki - Bacillariophyta (Diatoms). Wydawnictwo Uniwersytetu Gdańskiego, 154 pp.

35. Prarat W. 2009. Koryto „Starego Sanu”. [Old San river bed]. Chata. Pismo Kulturalno - Historyczne Gminy Gorzyce, 2, 247-252.

36. Qingmin Y., Yan L., Youfang W., Quanxi W. 2009. Taxonomy and distribution of diatoms in the genera Epithemia and Rhopalodia from the Xinjiang Uygur Autonomous Region, China. Nova Hedwigia 89, 397-430.

37. Reddy K.R., Agami M., Tucker J.C., 1989. Influence of nitrogen supply rates on growth and nutrient storage by water hyacinth (Eichhornia crassipies (Mart) Solms) plants. Aquatic Botany, 36, 33-43.

38. Reddy K.R., Agami M. Tucker J.C., 1990. Influence of phosphorus on growth and nutrient storage by water hyacinth (Eichhornia crassipies (Mart) Solms) plants. Aquatic Botany, 37, 355-365.
39. Round F.E., Crawford R.M., Mann D.G. 1990. The diatoms. Cambridge University Press, Cambridge, $747 \mathrm{pp}$.

40. Scheffer M., Van Geest G.J., Zimmer K., Jeppesen E., Søndergaard M., Butler M.G., Hanson M.A.,Declerc S., De Meester L. 2006. Small habitat size and isolation can promote species richness: second-order effects on biodiversity in shallow lakes and ponds. Oikos, 112, 227-231.

41. Sierszen M.E., McDonald M.E., Jensen D.A. 2003. Benthos as the basis for arctic lake food webs. Aquatic Ecology, 37(4), 437-445.

42. Sims P.A. 1983. A taxonomic study of the genus Epithemia with special reference to the type species E. turgida (Ehrenb.) Kütz. - Bacillaria, 6, 211-235.

43. Špoljar M., Zhang C., Dražina T., Zhao G., Lajtner J., Radonić G. 2017. Development of submerged macrophyte and epiphyton in a flow-through system: Assessment and modelling predictions in interconnected reservoirs. Ecological indicators, $75,145-154$.

44. Taylor J.C., Cocquyt C. 2016 Diatoms from the Congo and Zambezi Basins - Methodologies and identification of the genera. Abc Taxa 16,355 pp.

45. Toporowska M., Pawlik-Skowrońska B., Wojtal A.Z. 2008. Epiphytic algae on Stratiotes aloides L., Potamogeton lucens L., Ceratophyllum demersum L. and Chara spp. in a macrophyte-dominated lake. Oceanological and Hydrobiological Studies 37(2), 51-63.

46. Upadhyaya A.R., Mishraa V.K., Pandeya S.K., Tripathib B.D. 2007. Biofiltration of secondary treated municipal wastewater in tropical city. Ecological Engineering 30(1), 9-15.

47. Vishnyakov V., Kulikovskiy M., Genkal S.I., Dorofeyuk N.I. 2014. Taxonomy and geographical distribution of diatoms genus Epithemia Kützing in water bodies of Central Asia. Inland Water Biology, 7(4), 318-330.

48. Wiklund J.A., Bozinovski N., Hall R.I., Wolfe B.B. 2010. Epiphytic diatoms as flood indicators. Journal of Paleolimnology, 44(1), 25-42.

49. Wilk-Woźniak E., Walusiak E., Burchardt L., Cerbin S., Chmura D., Gąbka M., Glińska-Lewczuk K., Gołdyn R., Grabowska M., Karpowicz M., Klimaszyk P., Kołodziejczyk A., Kokociński M., Kraska M., Król W., Kuczyńska-Kippen N., Ligęza S., Messyasz B., Nagengast B., Ozimek T., Paczuska B.M., Pełechaty M., Pęczuła W., Pietryka M.,Piotrowicz R., Pociecha A., Pukacz A., Richter D., Żbikowski J. 2019. Effects of the environs of waterbodies on aquatic plants in oxbow lakes (habitat 3150). Ecological indicators, 98, 736-742.

50. Żmudziński L., Kornijów R., Bolałek J., GórniakA., Olańczuk-Neyman K., Pęczalska A., Korzeniowski K. 2002.Hydrobiological dictionary-terms, conceptions, interpretations, PWN, Warszawa. 